\title{
Compiled Hindsight? Publishers' Archives in South Africa
}

\author{
by Elizabeth le Roux
}

\begin{abstract}
Publishing is an important cultural industry, and its products form part of the record of our social and cultural history. Yet what of the records of the publishers themselves - the voluminous correspondence, financial information, manuscripts, policies, review reports, and so on - and what is preserved of such records? In this paper, I propose to discuss the ways in which South African publishers keep - and do not keep - archives. If we are to write a full publishing history in this country, then it is imperative that there should be archives, records, sources of information. Yet publishers, while concerned with record-keeping for corporate purposes, turn out to be not particularly good at keeping records for posterity, for examination, or for independent study. A key problem is access to source material for further study, as often it has not been retained, or certain corporate archives are closed to outsiders and considered confidential. This problem is the result of a tension between why such archives may have been compiled for 'management information', precedent, or compliance and what users such as historians or other researchers may seek in them. There is a core difference in what each party regards as valuable. In other words, we may view publishers and their products as part of a cultural industry, but they largely view themselves as business entities. Another problem with sources results from the repressive legislation of the past, which banned books, suppressed authors and constrained publishers. The effect was to create gaps, omissions and even excisions in the archives that survive. This paper aims to examine which kinds of traces survive, and under what circumstances, in the archives of South African publishers, using a case study approach. As part of a larger, ongoing project, this would be of use to researchers who are seeking to write publisher histories, as well as to publishing houses with haphazard policies for sorting and retaining records for archival purposes.
\end{abstract}

Zusammenfassung/résumé at end of article

received: 14.08.2012 revised: 11.01 .2013

\section{Introduction}

Publishing is an important cultural industry, and historians seeking sources look to its products as these form part of the record of our social and cultural history. These products, like the broader forms of records that are usually maintained and preserved in archives, make up society's "accessible memory" of itself (Brereton 1998). However, less attention has been given to the history of the publishing houses and to the potential sources for social history that may be located in the records of the publishers themselves - the voluminous correspondence, financial information, manuscripts, policies, review reports, and so on, that make up a publisher's corporate archive. 
With growing interest internationally in publishing history and book history, attention is now turning to the preservation of publishing records and archives. In this paper, I propose to discuss matters relating to the publishing history and archives of South African publishers.

\section{The Concept of Compiled Hindsight}

This paper draws on a number of theoretical and methodological constructs, reflecting the highly interdisciplinary nature of the field of publishing studies. The study of corporate archives, for instance, which falls largely under the broader study of organisational history, was an important framing device in this regard, especially in considering how corporate archives differ from historical archives. Concepts emerging from book history have also proved helpful as a basis.

A key concept, used as a trope throughout the paper, is that of compiled hindsight. This term originated in the areas of the history and philosophy of science, and finds its most widespread application in the study of artificial intelligence, especially by Douglas Lenat (1982) and Lindley Darden (1987). 'Compiled hindsight' is a distillation of knowledge and experience in a specific field, usually extracted from historical analysis. The term is used to indicate knowledge that is accepted as fact, and that then may serve as the basis for the progressive development of new knowledge. Douglas Lenat (1982) notes that "Heuristics are compiled hindsight; they are judgemental rules which, if only we'd had them earlier, would have enabled us to reach our present state of achievement more rapidly". A similar concept is that of "corporate DNA" (Kransdorff 2006).

The application of this concept in the case of archives enables us to distinguish between the functions of a publisher as well as the different uses to which archives are put (especially in the case of corporate archives). It is a concept that runs against the grain of theorists suggesting that "the record is always in the process of being made" (Harris 2007). Yet, it fits with the dual nature of publishing, which is at once a cultural industry and a business like any other. Similarly, archives can be used for cultural, historical or academic ends as well as for business purposes. On the one hand, scholars use corporate archives as a source for the writing and making of histories. On the other hand, they are both created and used by the staff of corporate organisations themselves, for utilitarian purposes, and are expected to offer compiled hindsight, to save time, energy, money - in a way similar to the Positivist position that Harris critiques. Corporate archives are also used by external gatekeepers, such as auditors, and they too expect the archives to reflect reality and to remain unchanging - after all, "reliable records make people and organisations accountable" (Thomassen 2001). 
If we look at the development and professionalisation of corporate archive-keeping, as described by Adkins (1997) for instance, we see that organisations tend to use archival resources "to assist companies in meeting their current business needs". She adds that these are "far from the business historians who wanted access to records in order to write scholarly articles and books" (Adkins 1997).

A tension thus exists between why records may have been kept and an archive compiled, and what users such as historians or other researchers may seek in them. This tension between primary and secondary functions is common for corporate archives: "The primary functions of records are the functions that the actor had in mind when creating them and in particular the evidential functions. In their primary function records play an active role: they document and regulate social relations. The secondary function of records is the function which the actor generally does not have in mind, and which records only acquire once they have fulfilled their primary functions: the cultural-historical function or the function of source for historical research" (Thomassen 2001). There is thus a core difference in what each party regards as valuable. In other words, we may view publishers and their products as part of a cultural industry, but they largely view themselves as businesses. In general, too, organisations tend to focus on the present, not the past. Thus, publishers tend to keep their records for functional reasons, such as legal purposes, when called upon to prove copyright ownership or assert intellectual property, for instance. They know little about longterm storage standards or issues of preservation. But this should not negate the importance of such records for what they reveal about our cultural heritage, because of the products with which publishers work.

\section{Access to Publishers' Archives}

In general, publishers, like any other organisation, while concerned with record-keeping for corporate purposes, are not particularly good at keeping records for posterity, for examination, or for independent study. Books and other paper records are often damaged by environmental exposure, to light, water or fire, for instance. Moreover, an ongoing problem for researchers is access to records: archives are frequently in a state of confusion and poorly organised, preservation appears to be haphazard with certain kinds of records retained and others regularly discarded, and certain corporate archives are closed to outsiders because they are considered confidential. Sometimes it is difficult to discern the reasons why particular archives came into existence, why they are organised in a particular manner, or why preservation appears to be ad hoc rather than systematic - the decision-making processes behind the archive. Sarah Nuttall quotes Wolframm Hartmann as asking, in this regard, "What happens when 
the archive has not been organised on long-standing principles, but has been assembled unevenly, haphazardly, anonymously - not even called an archive but a "collection" or a "library" - and not easily rendered up for scrutiny?" (Nuttall and Harris, 2002: 290).

Some publishers, internationally, maintain well-kept archives and have developed preservation policies that take researchers' needs into account. For instance, the historically significant UK publisher, Macmillan, has a huge archive (of more than 1250 volumes), which is now housed at the Department of Manuscripts at the British Museum. The publisher's website (Macmillan 2012) describes the main archive as follows:

The Macmillan Archive at the British Library contains correspondence with eminent writers, scientists, economists, illustrators and many others published by Macmillan including Charles Kingsley (Macmillan's first best selling novelist), Thomas Hughes, Charlotte M Yonge, Thomas Hardy, Henry James, Alfred Lord Tennyson, Rudyard Kipling, H G Wells, W B Yeats, J M Keynes, T H Huxley, Walter Pater, Alfred Russel Wallace, Sir James Frazer, Enid Blyton, Sean O'Casey, etc. In 1990 it was described as "one of the most important publishing archives ... an invaluable record of literary and publishing activity".

This archive has been described as important, "not only for its many literary autographs, but also for the light which it sheds upon author-publisher relationships" (Blake-Hill 1971). With the resources available, and granted the historical importance of the company, it is not surprising that at least four book-length histories of Macmillan have been written. While it is unclear whether the archives of Macmillan South Africa are included in these corporate archives, they have been used to produce a publishing history of Macmillan in another important colony, namely India (Chatterjee 2001), so the circumstantial evidence of there being material on South Africa is good. Jane Potter notes that "The international nature of the firm forms an important aspect of Macmillan's history and it demands further study from scholars, who will find much of relevance in the company's archive" (2003).

However, in spite of this being a shining example of a well-preserved archive, problems remain. For one thing, the archives offer only restricted access. Moreover, the archives are still not entirely centralised, as the records of certain imprints of Macmillan may be found in the Bodleian Library, Oxford, while those of the US office (Macmillan Company of New York) are housed in the New York Public Library. These are supplemented by an archive of 'less important' authors and documents at Reading University in the UK. In addition, a full archive of the Macmillan News, a newsletter produced by the head office for its offices around the world from 1962 to 1991 , is maintained by the publisher itself and is now available online. This fragmentation 
makes it more difficult to be certain that the most significant documents are being preserved. Decisions about what to retain are still made by the publisher, but the various different museums and libraries are now responsible for the actual storage and conservation of the existing records, and their adherence to standards in this regard may differ markedly.

Another culturally important publisher, Penguin, has similarly 'outsourced' its records collection and preservation to an external partner, in this case the University of Bristol, as part of an ongoing research project into the history of the publisher. Penguin holds a special mystique in the history of British publishing, and as a result, at least ten books have already been written on its history, including four on founder Allen Lane. The archive contains the records of Penguin Books Ltd. from its foundation in 1935, up to the 1980s. Some of the materials included refer to the establishment and business operations of Penguin Books, as well as social events, legal cases (particularly the landmark Lady Chatterley's Lover censorship trial of 1960), exhibitions on the company's history, and the private lives of prominent figures in the early history of the company. It also includes a large collection of Penguin books from 1935 to date. The majority of these papers were accumulated by Penguin Books to celebrate their fiftieth anniversary in 1985, as little had been systematically collected and preserved before that date. While the main research project provides excellent access to the archives, "Researchers wishing to use the Penguin Archive must first obtain written permission from Penguin Books Ltd" (Penguin Archive Project 2012). The University is now responsible for the preservation of the records it houses, and the collection is growing as more papers are donated each year.

Several publishing houses, only recently recognising the importance of their archives, have followed the example of using a university as a partner to preserve their records. As a result, Reading University in the UK now hosts a special collection of archives of publishers, including giants such as Random House, Jonathan Cape, and Secker \& Warburg, the Heinemann African Writers Series, and, as mentioned, parts of the Macmillan archive. A general catalogue on the website provides some online accessibility, but there are restrictions on what is available and under what circumstances. A similar collection of publishers' archives is hosted by the University of North Carolina, Chapel Hill, which includes publishers such as John Murray and the Grove Press.

To avoid the problems of storing massive quantities of perishable paper records, ProQuest has amassed a microfilm collection of archival material from a number of important British and US publishers, notably Cambridge University Press (16961902), Harper and Brothers (1817-1914), Longman (1794-1914), and George Rout-ledge \& Company (1853-1902). A similar online collection has been made in Canada: 
A website titled 'Historical Perspectives on Canadian Publishing' provides information about, and access to, a wide range of scanned archival materials, including author contracts, royalty statements, copyright certificates, marketing plans, sales reports, general ledgers, inventory books, and annual financial statements, to name but a few. The website is managed by McMaster University, in association with Queen's and Toronto University's archives. In general, Canadian publishers appear to be aware of the value of their historical records, and with the assistance of a number of universities, they have been able to preserve their older records in corporate archives that are managed and preserved by university archivists - although Brereton (1998) notes that only 33 publishing houses have lodged their records in institutional repositories, while another 40 maintain their own records, in-house. In other cases, records are discarded after seven years.

In contrast, the archive of Faber \& Faber is still maintained in-house: "With a distinguished history stretching back to the mid-1920s, and featuring many of the greatest literary and artistic figures of the twentieth century, Faber \& Faber has preserved a unique publishing archive. This is still an integral part of the company, and is used to support new editions, but is a great potential resource for anyone interested to learn more about the firm and its great authors" (Faber Archive 2012). This prestigious publishing house has made selections from its archive available online, including book reports, correspondence, book cover designs, and photographs. For instance, there is correspondence by and photographs of T.S. Eliot when he served as an editor (and as an author, naturally) for the company. In addition, the website features videos with the chief archivist talking about various books published over the years, PDF files of various documents, a timeline, and an audio tour of the Faber archive. This apparent openness serves to obscure the fact that these selections are very carefully made, for marketing rather than research purposes, and they represent only a tiny portion of the full extent of the archives - which may remind us of the comment that an archive involves "the selective transmission of [a] heritage" (Smith and Steadman, 1993). Moreover, the Faber archive is not open to outside researchers. In fact, it was opened to the public for the first time in May 2010 as part of a promotional event - a competition in which just seven people could spend a single evening in the archive. There is little information available on the full size or scope of the archives, nor on their state of preservation.

\section{South African publishers and their archives}

In contrast to the survey of publishers' archives briefly described above, South Africa has no comparative collections of archives or records. In general, South African 
companies appear to place little emphasis on the creation or preservation of corporate archives. A scan of the largest and most influential publishers in South Africa reveals that not one includes information about an archive or records collection on its website. At best, a few publishers have a short paragraph on their history under the 'About Us' tab. This includes historically important publishers such as Human \& Rousseau (now part of NB Publishers); David Philip (now an imprint of New Africa Books); Ad Donker (now an imprint of Jonathan Ball, part of Via Afrika); Heinemann and Maskew Miller Longman (now both part of the Pearson Group); the HSRC Press; Jacana Media; Juta; LAPA; Pan Macmillan; Random House Struik (owned by New Holland and Avusa); Shuter \& Shooter; Via Afrika (now part of Media24); and Van Schaik (now an imprint of Via Afrika, under Media24).

Indeed, South African publishers seem not to mention their archives even when there is a significant one available. For example, the anti-apartheid publisher David Philip's papers are now housed at the National English Literary Museum (NELM) in Grahamstown, and this collection has been described as significant for scholars: "Noone with an interest in the history of South African book publishing in the second half of the 20th Century can afford to overlook this most significant assemblage of literary and publishing materials" (NELM 2002). The website of the publishing house does, in fact, overlook this by omitting to mention its existence. NELM is now responsible for preserving the records that it holds - and has become increasingly sophisticated in its approach to long-term storage - but these are by no means complete and no systematic attempt has been made to select appropriate records for preservation. The collection includes correspondence with authors such as Alan Paton, yet has not to date been mined for a history of the publishing house - and may not be in a position to provide all the necessary details for a full history, given that it focuses on literary figures, and not on the business of publishing.

Similarly, on its website, the academic publisher Juta specifically mentions its important heritage - it is the oldest continuously operating publisher in South Africa, having been established in 1853 - but no further information is forthcoming. This is of interest, given that Juta does have a corporate archive and, using its own records, has published the first volume of a planned multi-volume history (De Kock 2007). Yet it makes no reference to this fact on its website. Juta's archive is incomplete, especially for its early years, as a fire in 1901 destroyed almost all its administrative records as well as the entire stock of the company. This is a reminder of the vulnerability of paper records, and the importance of good preservation policies.

Van Schaik Publishers, which was founded in 1915, is fairly typical of the South African publishers in terms of preservation of records. Its archives are kept in two locations, at least: Unisa Library maintains an archive of all books published by Van 
Schaik, while the main records, correspondence and old manuscripts are kept at the Van Schaik offices in Hatfield, Pretoria. The appropiate verb is 'kept', as the latter archives are simply locked away in a storeroom. They have not been catalogued, there is no attempt at maintaining the optimal conditions for the preservation of paper, and they are fragmentary and erratically maintained - even damaged. For example, some older correspondence on fax paper has faded over time through exposure to light, while other papers have deteriorated through being folded, stapled or bound together with rubber bands that are now crumbling. The quality of the archive is therefore uneven, although it is known to contain some culturally and historically important documents.

A similar situation has been found with South Africa's university presses: their records tend to be housed partly in the university libraries, partly in the corporate archives of the universities, and partly within the offices of the presses themselves. This leads to a case where, for example, the minutes of every Publications Committee meeting may be easily located at both Unisa Press and in the university's wellmaintained library archives (if suitable permission is obtained), but a file labelled as containing the most important founding documents of the press lies empty on a shelf in the publishing offices. Little attempt has been made to sift, to catalogue, or to store the most relevant records in a sustainable way. Similarly, the records of the University of KwaZulu-Natal Press are incomplete, as certain folders containing minutes of the meetings of the Publications Committee are missing from the corporate archives mislaid, misfiled, damaged or possibly even discarded.

A publisher that has received some scholarly attention, and that serves as an example of how historical research into a publishing house can shed light on other areas of study, is Lovedale Press. Yet it is almost by chance that the Press has a large and now well-preserved archive (at least for the years 1928 to 1953), in the Cory Library at Rhodes University. This appears to be an exceptional case, as in general South African universities have not become the custodians of publishers' records, and appear to have little interest in doing so. Jeff Opland has described in a paper (1990) how he chanced upon what would become the basis of the archive:

On one such visit, [the managing director, Rob] Raven and I descended a narrow flight of worn wooden stairs and turned a corner down an ill-lit corridor cramped by piles of papers stuffed into four tomato crates measuring about 3'x2'x2'. "What's this?" I asked. "Oh, that's just rubbish we're clearing out," Raven replied disinterestedly. I paused to leaf through some of the papers, and was immediately struck by what I saw. I urged Raven not to discard the boxes, and raced anxiously back to Grahamstown to meet hurriedly with Michael Beming, head of the Cory Library for Historical Research at Rhodes University; arrangements were speedily concluded, and a few weeks later I returned to Lovedale to load the boxes into the trunk of a 
car and transfer them to safe-keeping in the Cory Library. The contents far exceeded the high expectations aroused by my cursory inspection, and now constitute an indispensable collection for the study of the as-yet-unwritten history of Xhosa literature and the operation of the Lovedale Press. Amongst those papers, for example, was the unique typescript of Sol Plaatje's Mhudi (1930), the first novel in English published by a black South African; the typescript formed the basis of Stephen Gray's revised edition of Mhudi (1978). The papers included copies of Shepherd's correspondence with authors, readers' reports, minutes of committee meetings, and printing accounts. The collection has prompted an assessment of Shepherd's virtual control of Xhosa publishing that is somewhat at variance with the image of the benign patron he himself provides in his own writings.

Opland describes how the discovery and, later, preservation of this archive has enabled researchers to challenge the compiled hindsight that was in place about the role of Lovedale Press as an African-language publisher. This valuable archive is now accessible to researchers, through the Cory Library, but one can only imagine how often a similar 'clearing out' has taken place in South African publishers, without a keeneyed researcher there to prevent the loss of such records. I was personally able to save a few boxes of records and ledgers when an old storeroom at Unisa Press was cleared out and all the contents pulped, in 2009. This discarding of records is especially common among smaller publishers, as few small businesses tend to preserve their papers. Fredeman (1970) points out that, "Faced with endemic problems of storage, many publishers regularly destroy correspondence, business records, vouchers, and printing orders according to predetermined regulations and schedules in order to reduce the sheer bulk of accumulated papers, though some kinds of documents are classified 'Not to be destroyed', or 'Keep Always'." Even those marked 'Keep Always' may not be kept in accordance with standards for preservation of archival documents.

The matter of preserving an archive is also a key problem when mergers and acquisitions complicate the ownership structure of a publishing house. What happens to archives when a corporate entity changes hands? The story of Ravan Press may be instructive here. Ravan was a highly influential anti-apartheid publisher in the 1970s and 1980s. In 1994, the publisher could not sustain its operations, and in an attempt at survival, a 76\% stake was sold to Hodder \& Stoughton Educational. This was then sold to Pan Macmillan SA in 2000. Pan Macmillan has integrated some of the Ravan Press records into its own archives, as a result, but the full record is, at best, scattered. The archive is difficult to access and is not under the care of a trained archivist. Moreover, copies of correspondence as well as certain manuscripts are archived in NELM in Grahamstown, while state security records detailing the harrassment of the publisher by the security police are now housed in the South African History Ar- 
chives, and the William Cullen Library at the University of the Witwatersrand holds a collection of certain book titles. This fragmentation of record-keeping is unfortunately common among South African publishers. The story of Ravan Press that is available at present is thus not 'compiled hindsight', but rather fragmentary, anecdotal, biased and incomplete.

A full survey of the location and state of preservation of publishers' records would be of great value for continuing research into the history of publishing in South Africa. The author is in the planning phases of such a survey, which is expected to be an ongoing research project over a number of years.

\section{Corporate histories}

Why are South African publishers' archives in such a poor state of preservation and so difficult to access, generally speaking? If publishers value their records for functional reasons, then it follows that the records they preserve are being kept for similar reasons. Often, records are kept for legal reasons, and for the purposes of compiling a corporate history. Companies use such corporate histories for branding and marketing purposes, and to mark significant anniversaries. One of the very earliest corporate histories to be written was in fact that of a publishing house, which brought out popular street ballads: The History of the Catnach Press by Charles Hindley, in editions in 1869 and 1886. It was considered lengthy but not always reliable (Kransdorff 2006), which could unfortunately be said of many modern histories as well. Smith and Steadman (1993) argue that "A history of the company is an important though generally unexploited corporate resource. It has many values extending well beyond the celebratory function of the conventional 'company history', in either its publicity brochure or anniversary-book form."

An interesting example of the tension in the way we think about records and their value may be found in an organisation known as The History Factory. Their function is to advise businesses on compiling and maintaining archives, and helping them to write company histories. Far from an interest in social history or culture, they see historical records in purely commercial terms: "When you incorporate history into publications, they take on a depth, authenticity and brand ownability that can't be duplicated by any other means", because "Corporate histories can help you support a variety of goals, from sharing key corporate messages, to reinforcing elements of corporate culture, building employee pride and awareness, enhancing recruiting efforts, enlightening customers, commemorating achievements, and strengthening overall brand identity" (The History Factory 2012). This is history as written by marketing and communication teams, not by historians - history as a commodity. This is also 
advice on archiving from marketers, not archivists, and so questions of selection and preservation do not rate high on the agenda.

What we find in the absence of an objective history based on a full record are unscholarly, journalistic, and often management-sanctioned or commissioned corporate histories of publishing houses, as well as tributes and anecdotes. These are not critical analyses, and do not seek to problematize the history with which they are dealing. Smith (1993: 183) goes on to argue that company histories often "perpetuate vague memories, uncritical myths, and simplistic doctrines". A good example of the predominance of such 'compiled hindsight' in the stories that organisations tell about themselves is in the creation of myths, especially as regards the founding or corporate culture of the organisation. Indeed, "In the absence of extensive historical research, corporate culture writers have usually imposed upon the histories of companies a story about the founder creating a culture" (Rowlinson and Hassard 1993). This can be clearly seen in the history of publishers such as Penguin. To quote the official history on the Penguin website, and repeated in the promotional materials for countless Penguin titles (Penguin 2012):

\begin{abstract}
Penguin paperbacks were the brainchild of Allen Lane, then a director of The Bodley Head. After a weekend visiting Agatha Christie in Devon, he found himself on a platform at Exeter station searching its bookstall for something to read on his journey back to London, but discovered only popular magazines and reprints of Victorian novels. Appalled by the selection on offer, Lane decided that good quality contemporary fiction should be made available at an attractive price and sold not just in traditional bookshops, but also in railway stations, tobacconists and chain stores. He also wanted a 'dignified but flippant' symbol for his new business. His secretary suggested a Penguin and another employee was sent to London Zoo to make some sketches. Seventy years later Penguin is still one of the most recognizable brands in the world.
\end{abstract}

This commonly repeated myth may indeed be based on fact, but it omits certain important aspects of the record, such as the failed experiments at publishing paperbacks that had gone before, the use of the German publisher Albatross as a model for Penguin and its branding, and Lane's experiences in publishing. The result of such myth-making is that, even when 'documentary sources' have been consulted, it is the 'founder narrative' - the compiled hindsight - which has been imposed upon them. In the case of one of South Africa's oldest publishers, Juta, the historical focus tends to fall on the founder, Jan Carel Juta. Volume 1 of the Juta history, The House of Juta: Pioneer Publisher, focuses largely as its title suggests on the biography of the founder, with little attention paid to providing a full bibliography of titles published, sketching the interplay between the bookselling and publishing parts of the business, or assess- 
ing the impact of this publishing house. Much is made, moreover, of the fact (surely irrelevant to his publishing?) that his wife, Louisa, was Karl Marx's sister - a Google search will elicit this fact quite easily, showing how it has become part of the compiled hindsight of what we know about the company.

Another aspect of myth-making is the distortion of history, the possible whitewashing of past behaviour in particular. It seems unavoidable that any record or archive is altered over time. There are gaps, omissions, and even excisions. What is important is which traces survive and under what circumstances: "Far from being objective descriptions, accounts of key events in an organization's history reflect differential attention, selective perception, and incomplete recall. As organizational members strive at mutually acceptable interpretations of events, distortions and omissions multiply" (Rowlinson and Hassard 1993). This is not always intentional, but can become problematic when the distortions come to be accepted as fact or as compiled hindsight.

Such distortions can also create ethical problems. Booth and Rowlinson argue that "The darker side of corporate history, and how companies respond to revelations of their unsavoury past, raises interesting questions about the meaning and ethics of past business behaviour, and whether it can be studied for insights into contemporary dilemmas" (2006). They give the German multinational publisher Bertelsmann as an example. This is a very interesting example, as it shows how compiled hindsight can be undone by careful study of the existing record. The company of Bertelsmann dates back to 1835 , but its history was relatively untroubled until the Nazi period. In 1998, Bertelsmann took over Random House; the chairman, Thomas Middelhoff, in giving a talk described Bertelsmann as "one of the few non-Jewish media companies closed down by the Nazi regime". In his words, the reason for the publisher's closure in 1944 was that "We had been publishing books that were banned by the Third Reich as subversive. Bertelsmann's continuing existence was a threat to the Nazi attempt to control freedom of expression" (IHC 2000). This was in fact a myth perpetuated by the company regarding its history in the Nazi period, which had become fixed over the previous decades, and was featured, for instance, in the festschrift to mark its 150th anniversary. The company handled the ensuing controversy well, appointing the Independent Historical Commission (IHC) to research Bertelsmann's role in the Third Reich. It has since accepted the findings openly, and has made transparency part of its new corporate culture. A Corporate History department was established in October 2002, to document and preserve the company's history, and the archive is open to the public.

It is interesting that Bertelsmann's response to unwelcome findings from their archives was not to censor the record, or attempt to excise information. This transparency is perhaps the best that can be hoped for from a corporate archive, in terms of 
accessibility and a readiness to correct and amend the story that the records tell. It would be important to ascertain whether the South African publishers have maintained full records of their role during the apartheid years, although, judging by the wealth of information still available on censored works, it appears that the bureaucrats of the apartheid state maintained good records. Thus, even where books were banned, authors suppressed, and publishers intimidated, the record of this history appears to have remained intact. Further research into the archives will show more.

Primarily, then, corporate entities see their history and their archives as compiled hindsight, using the accomplishments and lessons of the past to gain competitive advantages. This is learning from the past at its most basic level, but it also implies an uncritical acceptance of a certain interpretation of the past and the lessons that could be learned. In contrast, most scholars would nowadays recognise that histories - even corporate histories - are socially constructed, and that interpretations of the past may change.

\section{Conclusion: Towards preserving South Africa's publishing past}

In his introduction to a series of articles on 'Archivists with an Attitude', John Brereton cautioned scholars "to begin asking what is missing from the archive and how it can get there. And we can also ask some questions while there is still time to act: Are there things we should be working to preserve right now? What can we do now to make sure current practices and materials will be accessible in the archives of the future?" (1999). This quotation brings us to the question of preservation. Without policies or guidelines in place, South African publishers will continue to preserve their records erratically and without an eye to history.

What is required is the preservation of only a small proportion of a voluminous record-keeping, but the question inevitably arises as to what should be kept. Brereton (1998) notes that existing guidelines for archives are not entirely applicable to publishing houses. She argues that they tend to emphasise the materials of greatest interest to secondary users, at the cost of retaining business records such as administrative and especially financial records, which are of greatest use to the creators of the records. Canada's Simon Fraser University has produced a small booklet to encourage publishers to preserve their records (Coles, 1989). A similar effort for South African publishers would be of great use, and a survey of archives and their preservation is now in its initial phases.

The development of preservation guidelines would be of use to researchers who are seeking to write publisher histories, as well as to publishing houses with haphazard policies for sorting and retaining records for archival purposes. A basic starting point 
would be the preservation, conservation and in some cases digitisation of "corporate historical records and artefacts deemed to be of permanent value in documenting the company's founding and subsequent growth" (Bakken, 1982). Decision-making guidelines are required, taking into account the significance and value of certain categories of records, while advice is also needed on how to preserve or digitise records. This could lead to the development of a rich - and sustainable - resource for future scholars.

\section{References}

Adkins, E. W.: The development of business archives in the United States: An overview and a personal perspective. The American Archivist 60, 1997: 8-33.

Bakken, D. A.: Corporate Archives Today. The American Archivist 45, 1982: 279286.

Blake-Hill, P.V. The Macmillan Archive. British Museum Quarterly 36(3/4), 1971: 74-80.

Booth, C., Rowlinson, M.: Management and organizational history: prospects. Management and Organizational History 1(1), 2006: 5-30.

Brereton, B.: Models vs. Reality: Appraising publishing records. MAS thesis, University of British Columbia, Canada, 1998.

Brereton, J. C.: Rethinking our Archive: A Beginning. College English 61, 1999: 474-576.

Chatterjee, R.: Macmillan in India: A Short Account of the Company's Trade with the Subcontinent. In: Elizabeth James (ed.). Macmillan: A publishing tradition 18431970. Basingstoke: Palgrave Macmillan, 2001.

Coles, L.: Archival Gold: Managing and Preserving Publishers' Records. Vancouver: Canadian Centre for Studies in Publishing, Simon Fraser University, 1989.

Darden, L.: Viewing the History of Science as Compiled Hindsight. AI Magazine 8(2), 1987: 33-41. 
De Kock, W.: The House of Juta. Volume 1: pioneer publisher, 1853-1903. Cape Town: Juta, 2007.

Faber Archive. Online: http://www.faber.co.uk/archive/ (Accessed 28 February 2012).

Fredeman, W. E.: The bibliographical significance of a publisher's archive: the Macmillan papers. Studies in Bibliography 23, 1970: 183-191.

Harris, V.: Archives and Justice: A South African perspective. Chicago: Society of American Archivists, 2007.

Independent Historical Commission (IHC). Bertelsmann im Dritten Reich. Berlin: IHC, 2000.

Kransdorff, A.: Corporate DNA: Using organizational memory to improve poor decision-making. Aldershot: Gower House, 2006.

Lenat, D. B.: The nature of heuristics. Artificial Intelligence 19, 1982: 189-249.

Macmillan. The Macmillan archive. Online: http://international.macmillan.com/ MacmillanNewsArchive.aspx (Accessed 28 February 2012).

National English Literary Museum (NELM). NELM News 38, November 2002.

Nuttall, S., Harris, V. (eds).: Refiguring the archive. Cape Town: David Philip, 2002.

Opland, J.: The Publication of A.C Jordan's Xhosa Novel "Ingqumbo yeminyanya (1940)". Research in African Literatures 21(4), 1990: 135-147.

Penguin. About Penguin. Online: http://www.penguin.co.uk (Accessed 3 March 2012).

Penguin Archive Project. Bristol University. Online: http://www.bristol.ac.uk/penguinarchiveproject/ (Accessed 28 February 2012).

Potter, J.: Review: Macmillan: A publishing tradition. SHARP News 12(2), 2003: 8. 
Rowlinson, M., Hassard, J.: The invention of corporate culture: A history of the histories of Cadbury. Human Relations 46, 1993: 299-326.

Smith, G. D., Steadman, L. E.: Present value of corporate history. In: Arnita A. Jones \& Philip L. Cantelon (eds), Corporate archives and history: Making the past work. Florida: Krieger Publishing Company, 1993.

Smith, G. D.: Why companies can't afford to ignore the past. In: Arnita A. Jones \& Philip L. Cantelon (eds), Corporate archives and history: Making the past work. Florida: Krieger Publishing Company, 1993.

The History Factory. Online: http://www.historyfactory.com (Accessed 3 March 2012).

Thomassen, T.: A first introduction to archival science. Archival Science 1, 2001: 373-385.

\section{Zusammenfassung}

Archivieren im Rückblick? Verlagsarchive in Südafrika

Das Verlagswesen ist ein wichtiger Bereich der Kulturindustrie und seine Erzeugnisse sind wertvolle Zeitdokumente unsere Sozial- und Kulturgeschichte. Doch wie steht es mit den Unterlagen der Verlage selbst - umfangreiche Korrespondenz, Finanzberichte, Manuskripte, Strategiepapiere usw. - und wie viel davon bleibt erhalten? Im vorliegenden Artikel wird erörtert, wie - oder ob überhaupt - südafrikanische Verlage ihre Archive führen. Für die Aufarbeitung der Geschichte des Verlagswesens in Südafrika sind Archive, Aufzeichnungen und Informationsquellen unerlässlich. Jedoch scheinen Verlage ihre Dokumente hauptsächlich zu Unternehmenszwecken aufzubewahren, während sie bei der Bewahrung von Unterlagen für die Nachwelt, zur Untersuchung oder unabhängigen Begutachtung, weniger sorgfältig vorgehen. Ein wesentliches Problem ist der Zugang zu Quellen für weiterführende Studien. Häufig werden sie nicht vollständig aufbewahrt oder bestimmte Teile der Unternehmensarchive gelten als vertraulich und bleiben Außenstehenden verschlossen. Diese Problematik lässt sich durch den Gegensatz zwischen dem ursprünglichen Zweck dieser Archive d.h. Aufbewahrung zur „Verwaltungsinformation“ oder aus Konformitätsgründen, einerseits und dem Interesse von Historikern und anderen Forschern andererseits erklären. Jede Seite misst unterschiedlichen Aspekten Wert bei. Mit anderen Worten, während wir Verlage und ihre Erzeugnisse als Teil unserer Kulturindustrie sehen, definieren sie sich selbst hauptsächlich als Unternehmen. Die Quellenproblematik ist zudem bedingt durch die repressive Gesetzgebung der Vergangenheit Südafrikas, die Bücher verbot, Schriftsteller unterdrückte und Herausgeber unter Druck setzte. Die Folgen sind unter anderem Lücken und fehlende oder gar nachträglich entfernte Dokumente in den 
bis heute erhaltenen Archiven. In diesem Artikel wird anhand einer Fallstudie untersucht, welche Spuren in den Archiven südafrikanischer Verlage unter welchen Bedingungen überlebt haben. Diese Analyse, die Teil eines umfassenderen, aktuell laufenden Projekts ist, richtet sich an alle Forscher, die sich mit Verlagsgeschichte befassen, sowie an Verlagshäuser, in denen in der Vergangenheit die Aufbewahrung von Unterlagen für Archivzwecke aber auch deren Vernichtung ohne jegliche Planung erfolgte.

\section{Résumé}

Rétrospective sur les archives? Archives des maisons d'édition d'Afrique du Sud

L'édition est un domaine important de l'industrie culturelle et ses produits sont de précieux documents d'époque qui illustrent notre histoire sociale et culturelle. Cependant qu'en est-il des dossiers des maisons d'édition eux-mêmes - une correspondance volumineuse, des rapports financiers, des manuscrits, des papiers stratégiques etc...- et qu'en reste-t-il aujourd'hui ? Dans le présent article on proposera de discuter si oui ou non - et comment - les maisons d'édition d'Afrique du Sud administrent leurs archives. Pour pouvoir écrire une histoire de l'édition dans ce pays il est indispensable de se référer aux archives, aux comptes-rendus (procès verbaux) et autres sources d'information. Cependant il semble que les maisons d'édition ne conservent leurs documents qu'uniquement pour des objectifs relatifs à l'entreprise et qu'elles ne sont pas particulièrement soucieuses de conserver les informations pour la postérité afin qu'elles puissent être analysées ou expertisées de façon indépendante. Un problème essentiel est d'accéder aux sources afin de mener des études complémentaires. Très fréquemment les archives sont incomplètes ou certaines parties ne sont pas accessibles aux personnes à l'extérieur de l'entreprise sous prétexte de confidentialité. Cette problématique peut s'expliquer par la différence qui existe entre le motif primaire pour lequel ces informations ont été conservées, c'est-à-dire la sauvegarde de l'information pour l'« administration de l'entreprise » ou pour des raisons de conformité d'une part, et l'intérêt des historiens ou d'autres chercheurs d'autre part.

Il y a une divergence fondamentale entre les points de vue dont les deux parties évaluent les différents aspects. Autrement dit, alors que nous considérons les maisons d'édition et leurs produits comme partie intégrante de notre industrie culturelle, celles-ci se définissent elles-mêmes par contre principalement en termes d'entreprise. Par ailleurs le problème concernant l'accès aux sources résulte aussi de la législation répressive du passé de l'Afrique du Sud qui interdisait certains livres, censurait des auteurs et exerçait une pression sur les maisons d'édition. Les conséquences sont entre autres des lacunes, des omissions et mêmes des suppressions ultérieures de documents dans les archives conservées aujourd'hui. Dans cet article on analysera à l'aide d'une étude de cas quelles sont les traces qui ont pu être conservées dans les archives des maisons d'édition sudafricaines et sous quelles conditions elles ont pu survivre. Cette analyse qui fait partie d'un projet plus large actuellement étudié s'adresse à tous les chercheurs qui se consacrent à l'histoire de l'édition ainsi qu'aux maisons d'édition dans lesquelles par le passé la conservation de documents d'archives ainsi que leur destruction auront été réalisées sans aucune planification. 


\section{Author and contact}

Elizabeth le Roux is a lecturer in Publishing Studies in the Department of Information Science at the University of Pretoria. She worked in the scholarly publishing industry for 12 years, most recently as Director of Unisa Press, before moving into academia. She has recently completed her $\mathrm{PhD}$ on the social history of the university presses in South Africa, and has now started working on a research project on South African publishers' archives.

Elizabeth le Roux

Department of Information Science

University of Pretoria

Lynnwood Road

Pretoria, 0002

South Africa

Mail: beth.leroux@up.ac.za 